Diabetologia 7, $133-135$ (1971)

(C) by Springer-Verlag 1971

\title{
Variations in Synalbumin Insulin Antagonism during Tolbutamide Tolerance Test
}

\author{
J.S. BAJAJ* and.J. VALLANCE-OWEN \\ Department of Medicine, The Queen's University of Belfast, Belfast, Northern Ireland
}

Received: December 10, 1970, accepted: March 29, 1971

\begin{abstract}
Summary. Albumin was extracted from plasma and serum taken during intravenous Tolbutamide tolerance tests in 18 healthy volunteers and tested at a concentration of $2.5 \mathrm{~g}$ per $100 \mathrm{ml}$ for insulin antagonism. A significant rise in insulin antagonism was observed after 30 and $60 \mathrm{~min}$, falling to the initial level at $90 \mathrm{~min}$ following Tolbutamide injection. These changes were inversely related to the corresponding blood sugar levels.
\end{abstract}

Variations dans l'antagonisme de la synalbumine visà-vis de l'insuline au cours de tests de tolérance au tolbutamide

Résumé. L'albumine a été extraite du plasma et du sérum prélevé au cours de tests de tolérance au tolbuta. mide intraveineux chez 18 volontaires en bonne santé, et testée à une concentration de $2.5 \mathrm{~g}$ pour $100 \mathrm{ml}$ pour y déceler l'antagonisme à l'insuline. Une augmentation significative de l'antagonisme à l'insuline a été observée après 30 et $60 \mathrm{~min}$, le taux initial était atteint $90 \mathrm{~min}$ après l'injection de tolbutamide. Ces modifications étaient inversement proportionnelles aux taux correspondants de la glycémie.

Schwankungen des Synalbumin-Insulin-Antagonismus während des Tolbutamid Toleranz-Tests

Zusammenfassung. Bei 18 stoffwechselgesunden Freiwilligen wurde Albumin aus während eines TolbutamidTests entnommenen Plasma- und Serumproben extrahiert und in einer Konzentration von 2,5 g\% auf Insulin-Antagonismus getestet. Nach 30 und $60 \mathrm{~min}$ fand sich ein signifikanter Anstieg des Insulin-Antagonismus und $90 \mathrm{~min}$ nach der Tolbutamidgabe ein Abfall auf die Ausgangswerte. Die Veränderungen verhielten sich umgekehrt proportional zu den jeweiligen Blutzuckerspiegeln.

Key-words: Antagonism, insulin, rat diaphragm, synalbumin, tolbutamide.

\section{Introduction}

Patients with 'essential' or idiopathic diabetes mellitus have increased insulin antagonism associated with their plasma albumin - an exaggeration of that also found in the albumin fraction from healthy people [11]. In the physiological range of concentration $(3.5-5.5 \mathrm{~g}$ per $100 \mathrm{ml})$, both diabetic and normal albumin completely inhibit the effect of 1000 microunits per $\mathrm{ml}$ of insulin added in vitro to the incubation medium [13]. At $1.25 \mathrm{~g}$ per $100 \mathrm{ml}$ however, the albumin from essential diabetics as well as those constituted as diabetics, is still highly antagonistic (synalbumin positive), whereas albumin prepared from healthy subjects does not exhibit insulin antagonism (synalbumin negative). Recent in vivo studies lend further support to these observations [7, 8].

Synalbumin insulin antagonism changes during oral and intravenous glucose tolerance tests, the antagonism being inversely proportional to the glucose levels in the blood [6]; which suggests that the effectiveness of any circulating insulin is modified by alterations in synalbumin antagonism which in turn are mediated through changes in blood sugar. In previous studies the blood glucose rose initially; accordingly we have studied intravenous tolbutamide tolerance tests where the immediate response is a fall in glucose levels.

* Present Address: The All India Institute of Medical Sciences, Now Delhi, India

\section{Volunteers and Methods}

Eighteen healthy doctors and laboratory personnel, aged 20-27, were studied after a twelve hour fast. After withdrawing fasting blood sample in a heparinised syringe, $20 \mathrm{ml}$ of $5 \%$ sodium tolbutamide was injected intravenously during a two minute period; the midpoint of injection was considered as zero minute and subsequent blood samples were collected at thirty, sixty and ninety minute intervals. The subjects were rested for the duration of the test. The glucose concentration was estimated in all samples. Albumin was extracted from the plasma by a modification [13] of the Debro method [2].

In two volunteers, blood samples were collected in nonheparinised dry syringes and after taking adequate aliquots for glucose estimation, blood was allowed to clot. Serum was separated and albumin was prepared by the Fernandez method [4] which does not require the use of trichloracetic acid or dialysis; albumin prepared by this method has previously been found to be equipotent to that prepared by the Debro method, regarding insulin antagonism [18].

Insulin antagonism was determined by the ratdiaphragm procedure $[15,16]$. Albumin extracts were dissolved in buffer solution [5] containing glucose (300 mg per $100 \mathrm{ml}$ ); insoluble matter was removed by centrifugation. Insulin was added to the buffer alone and to the buffer containing $2.5 \mathrm{~g}$ albumin per $100 \mathrm{ml}$ to make a final concentration of 1000 microunits per 
ml. This concentration of albumin is the same as that used in the previous study of synalbumin changes during glucose tolerance test [6]. The glucose uptake of the diaphragms was determined in: [1] buffer alone; [2] buffer and insulin; and [3] buffer and $2.5 \%$ albumin in the presence of insulin. All the samples from one tolbutamide test were assayed in any one experiment, thereby facilitating the comparison between antagonistic effects of samples taken during the same test.

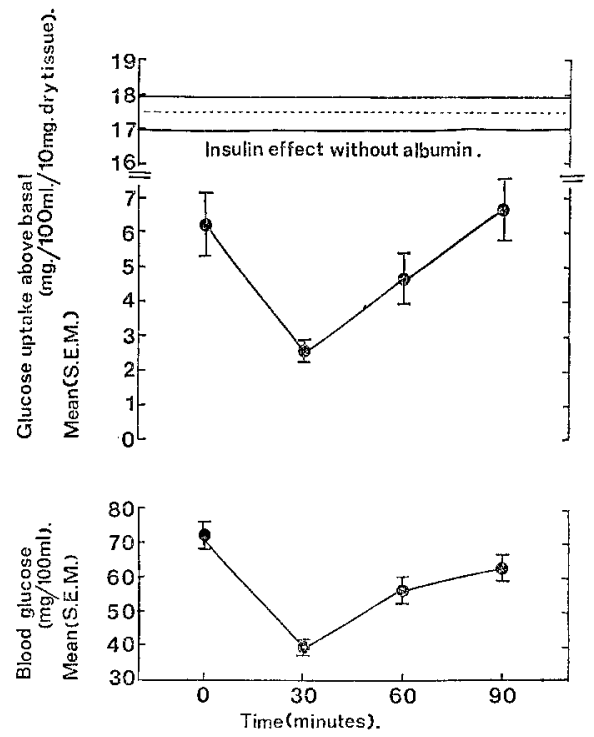

Fig. 1. Effect of insulin on the glucose uptake of the rat diaphragm in the presence of albumin samples tested at $2.5 \%$ taken during 18 intravenous tolbutamide tolerance tests, with the corresponding blood glucose values

\section{Results}

Figure 1 shows the mean values for the effect of insulin in the presence of $2.5 \mathrm{~g}$ albumin per $100 \mathrm{ml}$, extracted at various time intervals after tolbutamide administration. In all the volunteers, the insulin effect on the diaphragm showed a significant decrease at $30 \mathrm{~min}$; this coincided with the peak hypoglycaemic response in the subjects. Clinical symptoms of hypoglycaemia were noticed in five individuals; their blood. glucose concentration ranged between $27-40 \mathrm{mg} \%$ at this point. The increased antagonism at $30 \mathrm{~min}$ returned. to the pre-tolbutamide levels at $90 \mathrm{~min}$. There was no difference in these results when the albumin was extracted by the Fernandez method, therefore all the results have been given together in the figure.

\section{Discussion}

In healthy volunteers, the level of synalbumin insulin antagonism varies considerably and consistently after intravenous administration of sodium tolbutamide; it increases significantly thirty minutes after the injection and subsequently tends to fall to the inital fasting levels by $90 \mathrm{~min}$.

In contrast to these findings, Devrim et al. [3] in six normal subjects found that the increased antagonism at $30 \mathrm{~min}$ after tolbutamide continued to rise up to $120 \mathrm{~min}$ and suggested that this was due to the rise in plasma insulin following intravenous tolbutamide. However, glucose also causes a rise in plasma insulin but with a fall in antagonism [6]. Thus from this observation and the studies reported here the changes in synalbumin are related inversely to the blood sugar.

There is considerable evidence that the synalbumin antagonist is identical with the $B$ Chain of insulin [12] and liver contains a high concentration of glutathione insulin transhydrogenase which breaks the insulin molecules into its component $A$ and $B$ Chains $[9,10]$. Moreover, hypophysectomy [14] and adrenalectomy [17] are known to reduce the level of synalbumin antagonism and growth hormone stimulates glutathione insulin transhydrogenase [1]. Thus the short term variations in the level of synalbumin antagonism after tolbutamide as well as those previously reported after glucose administration could well be due to changes in pituitary-adrenal activity which in turn is governed by acute fluctuations in blood sugar.

Acknowledgment. We wish to thank the British Diabetic Association for financial support; Hoechst Pharmaceuticals for supplying the sodium tolbutamide and the Medical Research Council for the awared of a Senior Visiting Fellowship to J.S.B.

\section{References}

1. Costiner, E., Milcu, St.M., Oprescu, M., Simionescu, L.: The anti-insulinic activity of the growth hormone. Abstracts of Seventh Congress of the International Diabetes Federation, p. 54. Amsterdam, Excerpta Medica Foundation 1970.

2. Debro, J.R., Tarver, H., Korner, A.: The determination of serum albumin and globulin by a new method. J. Lab. clin. Med. 50, $728-732$ (1957).

3. Devrim, S., Kilo, C., Voyles, N., Recant, L.: Effects of tolbutamide and insulin on insulin inhibitory activity associated with plasma albumin. Diabetes 17, $746-751$ (1968).

4. Fernandez, A., Sobel, C., Goldenberg, H. : An improved method for determination of serum albumin and globulin. Clin. Chem. 12, 194-198 (1966).

5. Gey, G.O., Gey, M.K.: Maintenance of human normal cells and tumor cells in continuous culture: Preliminary report: Cultivation of mesoblastic tumors and normal tissue and notes on methods of cultivation. Amer. J. Cancer 27, 45 (1936).

6. Jervell, J., Vallance-Owen, J.: Variation in synalbumin insulin antagonism during glucose tolerance tests. Lancet 1967 II, $1253-1255$.

7. - - In vivo effect of the synalbumin and B-chain albumin insulin antagonist. Lancet 1967 II, 21-22.

8. Kammerer, L., Vallance-Owen, J.: In vivo effects of the synalbumin insulin antagonist. Diabetologia 4 , $336-338$ (1968).

9. Katzen, H.M., Stetten, D., Jr.: Hepatic glutathioneinsulin transhydrogenase. Diabetes 11, 271-280 (1962). 
10. Tomizawa, H.H., Halsey, Y.D.: Isolation of an insulin-depending enzyme from beef liver. J. biol. Chem. 234, 307-312 (1959).

11. Vallance-Owen, J.: Synalbumin insulin antagonism and diabetes. Ciba Found. Colloq. Endocrinol. London, Churchill 15, 217-234 (1964).

12. - Insulin antagonists in On the nature and treatment of Diabetes, Leidel, B.S. and Wrenshall, G.A., eds. p. 340-353, Amsterdam, Excerpta Medica Foundation (1967).

13. - Dennes, E., Campell, P.N.: Insulin antagonism in plasma of diabetic patients and normal subjects. Lan. cet 1958 II, $336-338$.

14. - - - The nature of the insulin antagonist associated with plasma albumin. Lancet $1958 \mathrm{I}, 696-697$.
15. - Hurlock, B.: Estimation of plasma insulin by the rat diaphragm method. Lancet $19541,68-72$.

16. - - Please, N.W.: Plasma-insulin activity in diabetes mellitus. Lancet $1955 \mathrm{H}, 583-587$.

17. - Lilley, M.D.: An insulin antagonist associated with plasma albumin. Lancet $\mathbf{1 9 6 1}$ I, 804-806.

18. - McMaster, D.: Serum-albumin and insulin antagonism. Lancet $1968 \mathrm{II}, 1192-1193$.

Prof. Dr. J. Vallance-Owen Department of Medicine Queen's University of Belfast Grosvenor Road Belfast 12, Northern Treland 